\title{
John McCrae on death
}

Heavy gunfire again this morning. Lieut. H[elmer] was killed at the guns. His diary's last word were, 'It has quieted a little and I shall try to get a good sleep.' I said the Commital [sic] Service over him, as well as I could from memory. A soldier's death! - John McCrae, letter of Sunday 2 May $1915^{1}$

$\mathrm{T}$ he poetry of Canadian physician and soldier Dr. John Alexander McCrae (18721918) can be viewed as revolving around a single idea: The presence and surpassing beauty of death, often for a martial purpose. This is perhaps best exemplified in his most famous work, the World War I memorial poem and perennial Remembrance Day favourite, In Flanders Fields. The poem starts with that gentle emblem of oblivion, the poppy:

In Flanders fields the poppies blow Between the crosses, row on row That mark our place; and in the sky The larks, still bravely singing, fly Scarce heard amid the guns below.

Note the understated "our" which refers to the dead who populate the fields. The second stanza is more explicit, personifying death:

We are the Dead. Short days ago We lived, felt dawn, saw sunset glow, Loved and were loved, and now we lie, In Flanders fields.

Death is McRae's great subject. It occupied huge aspects of his work as both a physician and a soldier and, judging by how frequently it appears in his + art, one can conclude it possessed his imagination too. But as is so typical of McCrae, ever the industrious soldier and doctor, even his imagination was put to a useful purpose. Thus what would become his most cited poem moves earnestly to argument:

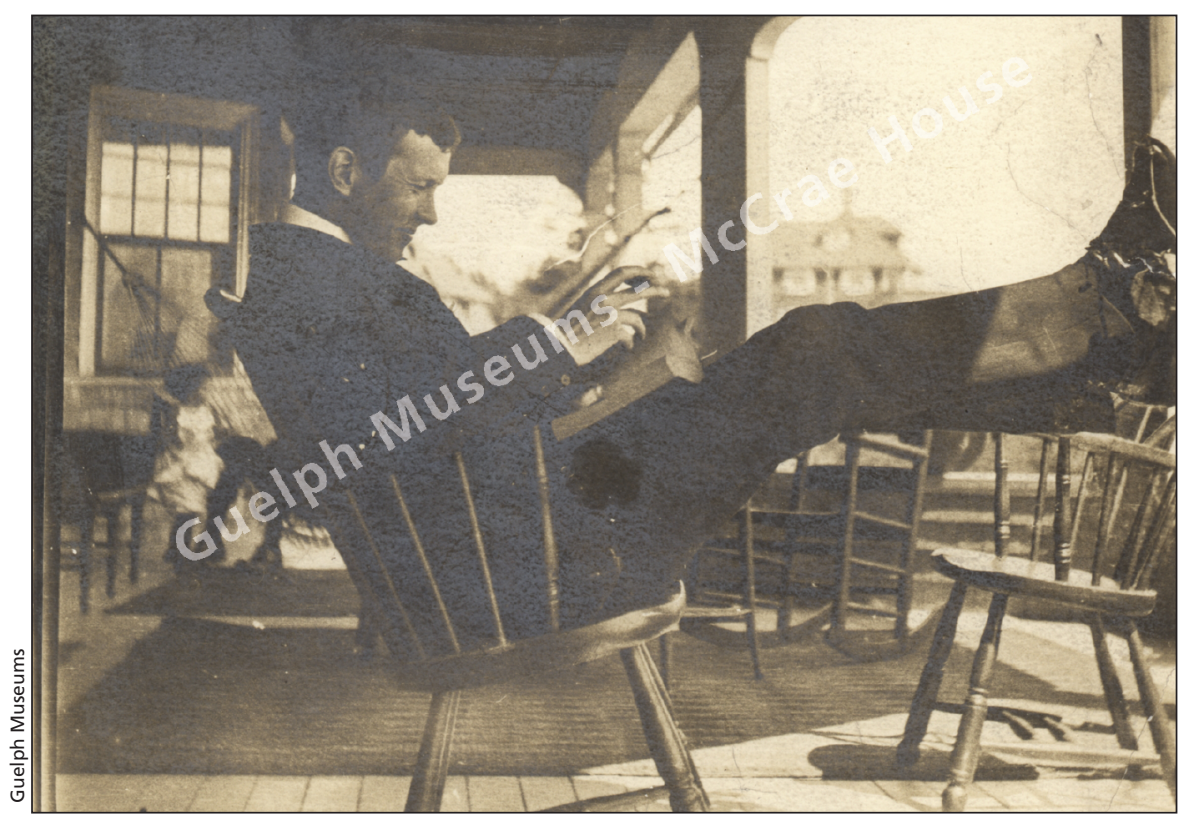

John McCrae at the summer home of Edwin Packard at Kennebunkport, Maine, in September 1903.

Take up our quarrel with the foe: To you from failing hands we throw The torch; be yours to hold it high. If ye break faith with us who die We shall not sleep, though poppies grow In Flanders fields.

Unquestionably the poem, which was used widely on war bonds advertisements and other promotional efforts, became a kind of cattle call to recruitment, but its popularity transcends its use in marketing. The reason why this rondeau became so popular and why it is the vehicle for remembrance of all the Commonwealth countries is that it concisely, and with simple, but not easy rhymes, articulates struggle. It is an accounting of the feelings of men who are dying and whose dying, while not glorified, demands a certain respect. He acknowledges this respect by using the proper noun: Death.

McCrae's first biographer, John Prescott, called In Flanders Fields a "bloodthirsty little poem." I concur, it is blood-slaked, but clearly it is also aesthetically earned, for its author has contemplated the subject many times before. In Flanders Fields followed a number of poems that used the dead as their speaking subjects, including Penance, A Song of Comfort, Disarmament, The unconquered dead and The Night Cometh. McCrae's prose antecedent to In Flanders Fields, an article published much earlier about his involvement in the Boer War, also honours death and sacrifice:

"The same evening I attended service in the Cathedral ... there was a strange appropriateness that one of the hymns should be 'Conquering Kings their titles make From the foes they captive make.'

For, stretching over the hill from the south wall in long dark rows, lay two thousand graves, where men slept that King Death had led captive, who were done with Kingdoms and republics; men whose message goes to the Empire, to 
the voice of a new colony that they had won by blood, - 'O stranger, go thou; and tell our people that we are lying here having obeyed their words.",

Here too, McCrae has capitalized and personified Death, but the piece differs from In Flanders Fields in that it is squared against sacrifice. Underlying it is the question: "Is this expenditure worth it?" A simple restatement of the verse McCrae quotes might be "Generals die in bed." The dead of Flanders emphatically care about the purpose and meaning of the battles they fought; the dead in this earlier piece are "done with kingdoms and republics." Despite these misgivings, which are rather atypical in the McCrae oeuvre, the attitude of profound respect toward death is of a piece with the famous poem. As Prescott states, "There remained with him always an awareness of life's transience and a fervent commitment to duty."

McCrae was not a poet composing odes from afar or during peacetime; he was in the thick of things as both a soldier and physician. Before he was a doctor, he was closely involved with the militia and won an award for being the best drilled cadet in Ontario. He served in the Boer War as a soldier, rather than a physician. In World War I, he was not only a brigade surgeon, he was also, rather unusually, second-in-command of the brigade and gave combat orders. In one of the typical gestures that no doubt contributed to his own death by pneumonia, he insisted in sleeping in tents like the regular men and not in officers' huts until his health so declined that he was ordered to do so. All of this is to say that McCrae earned his right to comment upon the soldierly duty to be called to die. He was a professional expert in death in all three careers: soldier, doctor and poet. And, in contrast to other war poets, including Sigfried Sassoon and Wilfred Owen, he emphatically believed in the causes - God and country - he was engaged in.

Even the most cursory glance at McCrae's oeuvre cannot escape its morbidity, its concern with death. In the definitive pamphlet of McCrae's poetry published by his medical colleague and man of letters Sir Andrew Macphail, there are 29 poems. $^{2}$ Perhaps five of them do not mention death; all the others mention, at the least, shadow and darkness. Prescott, wrote that "Many of the poems written in McCrae's early manhood, and some written after 1900, have a preoccupation with death. The achievement of peace after death was a constant theme in his poetry." It is not widely known that McCrae helped MacPhail with The Book of Sorrow, a collection of poems about bereavement and sorrow. It was over 500 pages long.

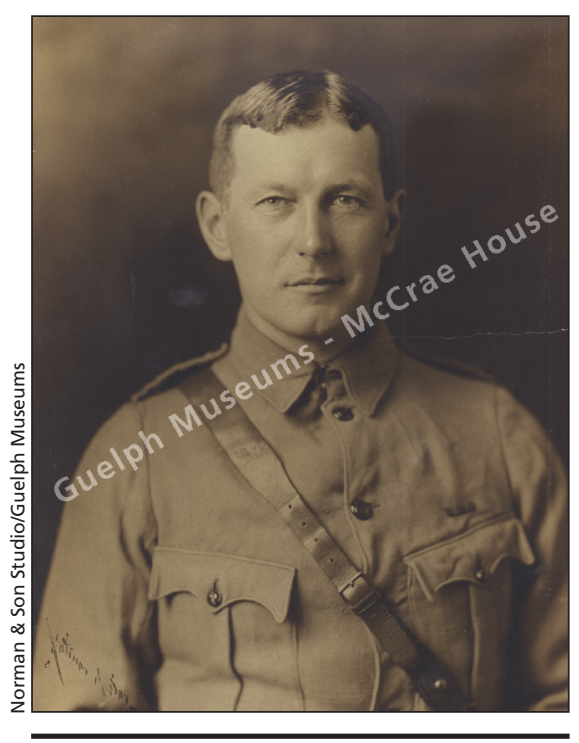

McCrae, pictured here in his World War I uniform, was on holiday in England on Aug. 4,1914, when Canada declared war on Germany. He immediately volunteered.

Why this morbidity? In medical school, choosing the career of pathology, as McCrae did, is tantamount to an admission that one wishes to practise medicine divorced from patient contact. The cliché is that the nascent pathologist is not well-disposed or skillful with people. But this was not the case with McCrae. Both his biographers take great pains to emphasize McCrae's genuine affability, describing him as hale and the possessor of an inexhaustible trove not a one repeated - of anecdotes. He kept the company of people such as the humourist Stephen Leacock, was a darling of Sir William Osler and beloved by the students he instructed at McGill University in Montréal, Quebec. And pathology at that time was not as pejorative as it is perceived by students now; McCrae took it up "with the wholehearted support of Osler, who believed that a good grounding in pathology was vital to success in medicine." ${ }^{4}$ Nevertheless, the fit between McCrae and pathology in the modern sense is undeniable. Prescott quotes the following inscription by McCrae, which has an ancient origin, in the 1902 autopsy book of the Montréal General Hospital:

Here begynneth ye Booke of ye Deade, wherin is fayrely set foorth ye last state of four Hundred and seventeen persones, that have departed from this lyfe; wherein be tabled diverse and straunge and fearsome condicions that have leddde to ye same final ende: God have them of his grace.

\section{Our lyfe is but a Winter's Day}

Some only breadfast and away. Others to dinner stay, and are fulle fedde.

The oldest man but suppes, and goes to bedde.

Large is his dette, that lingers out the day.

He that goes soonest has the least to pay!! ${ }^{9}$

It could be argued that McCrae, well-liked and sought after by women, only expressed what really concerned him when he sat down to write poetry. McCrae's biographer of note, Dianne Graves, writes, "Outwardly John could always be relied upon to appear cheerful and to present the lighter side of his nature in his daily dealings with the world at large. Underneath his friendly, outgoing exterior, however, he looked at everyday life through the consciousness of a personal spiritual dimension. A reflective sadness pervaded much of his writing...."4

Graves speculates about the origins of McCrae's morbidity. She transcribes part of a letter that McCrae wrote to his mother about his first love who died of typhoid: "Perhaps it is because I was brought into nearer connection with death, than I have ever been before, that I think so much about it." ${ }^{\prime 4}$ It is likely this love, so refreshing in McCrae's poetic output, and so against type, is the stimulus behind Unsolved and the outright love poem Then and Now." Without these poems, McCrae's poetry could be thought of as pathological, failing to survey what sacrifice is actually for. 
What is it for? Was Flanders' glorification of death in time of war solely a patriotic gesture? No. All poets are trying to work out for themselves their own true feelings. McCrae is working out for himself a means of preparation for death. Indeed, a few months before he died, McCrae was thought to be suffering from depression. It would go too far to say that he had lost faith with those who died, but perhaps not too far to say he certainly despaired for them. Prescott writes that "After the battle of Ypres he was never again the optimistic man with the infectious smile. His friends spoke of his change in temperament in subdued voices, feeling, as one said, that an "icon had been broken."

McCrae was a church-going man and is recognized as having a profound faith. Yet the poetry is remarkable in that despite being steeped in death, only two poems make an explicit claim that there is an afterlife: The Dying of Pere Pierre and The Dead Master. Prescott says that "He never seems to have questioned Christianity," but perhaps, once again, it is in his poetry that McCrae is most honest.

This poet/soldier/doctor conceived of nobly won death as its own reward, that the dying soldier achieves perfection. And 91 years after his death, playing that very old death-soaked game of looking for posthumous clues, it seems as if McCrae achieved it, dying of pneumonia - in fact declaring that he "knew it was the end" - and provoking an outpouring of grief across the empire. As McCrae foretold in the last line of The Pilgrims: "And this was death." The point is made again with the poppy every November 11th.

\section{Shane Neilson MD}

Family physician

Guelph, Ont.

\section{REFERENCES}

1. Prescott JF. In Flanders Fields: The Story of John McCrae. Guelph (ON): Guelph Historical Society; 2003.

2. MacPhail, A. In Flanders Fields and other poems by Lieut.-Col John McCrae, MD with an essay in character. Toronto (ON): William Briggs; 1919.

3. Macphail A (ed). The book of sorrow. London (UK): Oxford University Press; 1916.

4. Graves D. A crown of life: The world of John McCrae. St. Catharines (ON): Vanwell Publishing Limited; 1997.

\section{POETRY}

\section{Sons and mothers}

Little Ali falls from his tree

Hard grounded by Sir Isaac's gravity.

His Afghan mother bears him to Grace Emergency.

Slender arm greensticked

Split his ripe cherry lip

Nose bloodied, his lashes tear dipped.

English makes him old, her young

She who was once the harness maker's most beautiful daughter

Now greyed by worry and by war.

Lip stitched, face washed, arm in a plaster sleeve

Mother and son, hand in hand, hand in sling

Take their leave.

That Kandahar day

Zach Barkman is blown from life's tree

He of Patricia's own Canadian Infantry

She who was once granddaughter to an Empress Queen

But all our Queen's medics and all our Queen's men

Can not bring Barkman to life again.

Nor can all the acred lowland poppies

Nor a single highland piper

Make the pain go.

On the low road to Shilo

Of his fathers love begotten

Baby Barkman rocks, anchored to his corded roots

He can not hold his mother's hand, yet

Hercules will gently bear the fallen father home

Under a blood red leaf.

And ancient Eden's apple tree

Is lifted up again.

\section{Larry Reynolds MD}

Professor

University of Manitoba

Winnipeg, Man.

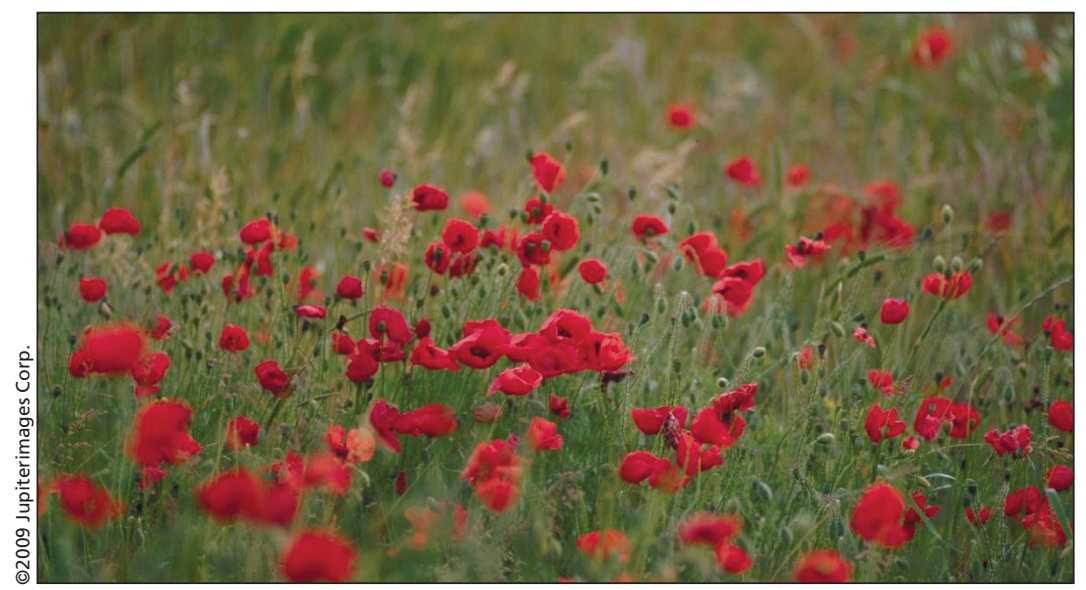

